\title{
Adrenoleucodystrophy: a molecular genetic study in five families
}

\author{
R G Del Mastro, S Bundey, Michael W Kilpatrick
}

\begin{abstract}
A genetic study has been performed on five adrenoleucodystrophy families using DNA probes from Xq28. Members of each family had previously been tested for carrier status using the biochemical assay for very long chain fatty acids (VLCFAs), but several persons at risk had equivocal results. DNA analysis with four DNA probes St14-1 (DXS52), DX13 (DXS15), MN12 (DXS33), and hs7 showed no crossovers between them and the disease locus in persons who were clinically affected or had high levels of VLCFA or both. Thus, the genotypes provided by the DNA probes could be used for accurate carrier detection and prenatal diagnosis could be offered. Of the 17 at risk females with VLCFA levels in the normal (1 SD) range, five were defined as carriers and 12 were considered not to be.
\end{abstract}

Adrenoleucodystrophy (ALD) is an $\mathrm{X}$ linked progressive neurological disorder. It is characterised by demyelination of the central nervous system and adrenal insufficiency. ${ }^{1}$ The age of onset of the disease is between 4 to 8 years with the progressive development of dementia, cortical blindness, ataxia, and spastic weakness in the limbs. ${ }^{1}$ The onset of the adult variant adrenomyeloneuropathy (AMN) is between the second and third decade. It progresses more slowly than ALD and affects the adrenal cortex, the spinal cord, and the peripheral nerves rather than the cerebral white matter. ${ }^{2}$

The biochemical defect in ALD and AMN results from the inability to breakdown very long chain fatty acids (VLCFA) in the peroxisomes. ${ }^{3}$ The protein responsible has been identified as peroxisomal lignoceroyl-CoA ligase which activates fatty acids (lignoceric

\footnotetext{
University of Birmingham, Department of Clinical Genetics, Birmingham Maternity Hospital, Edgbaston, Birmingham B15 2TG.

R G Del Mastro, S Bundey, M W Kilpatrick

Correspondence to Dr Del Mastro.
}

Received for publication 28 December 1989

Revised version accepted for publication 8 May 1990. acid, C24:0) by adding an acyl-CoA. ${ }^{4}$ This activation of the fatty acid is the first step of five in the peroxisomal beta oxidation system. It is here that the accumulation of VLCFAs occurs owing to the impairment of this enzyme. The gene responsible for this disease has not been isolated, but close linkage with G6PD has assigned the genetic defect responsible for ALD to Xq28. ${ }^{5}$

Biochemical methods for determining carrier status consist of assaying hexacosanoic acid (C26:0) in plasma and cultured fibroblasts, and comparing this level to that of other very long chain fatty acids. In this way up to $93 \%$ of obligatory heterozygotes can be identified, the remaining $7 \%$ having results in the normal range. ${ }^{6}$ By making allowance for this overlap between obligatory heterozygotes and normals, Moser et at $t^{6}$ concluded that about $77 \%$ of mothers of isolated cases were carriers. However, because of uncertainty in advising individual women, Moser et al $t^{t}$ suggested that women at high pedigree risk of being carriers should be offered prenatal diagnosis of ALD, as measurement of VLCFA on cultured amniotic and chorionic cells is a reliable diagnostic test for affected males.

In order to improve the detection of carriers, linkage to DNA markers has been sought. The highly polymorphic DNA probe St $14-1$ has been shown to be tightly linked to $A L D\left(Z \max =19 \cdot 10\right.$ at $\left.\theta=0 \cdot 00^{7}\right)$ and has been used in ALD families to supplement the biochemical assay. ${ }^{8}$ The DNA probe hs7 which detects the red-green pigment genes is also found to be tightly linked to $A L D .^{9}$

In this study we present DNA analysis with St 14-1 on five ALD families. These data are used to improve the assignment of carrier status for persons with equivocal VLCFA levels. Further DNA probes from Xq28 (MN12, DX13, and hs7) have been used in an attempt to determine an order with respect to the ALD gene, and to extend the scope of carrier detection and prenatal diagnosis.

Materials and methods BLOOD SAMPLES

Samples of blood $(20 \mathrm{ml})$ were collected in potassium EDTA tubes from each member of the five ALD families under study. 


\section{VLCFA MEASUREMENTS}

These were performed on plasma, as previously described, ${ }^{6}$ by Dr $\mathrm{H}$ W Moser at the John F Kennedy Institute. The level of hexacosanoic acid (C26:0) was the mean of two separate measurements: 1 SD above the normal mean was $0.51 \mu \mathrm{g} / \mathrm{ml}$ and the $2 \mathrm{SD}$ level was $0.69 \mu \mathrm{g} / \mathrm{ml}$.

\section{DNA PROBES}

St $14-1$ is a $3 \mathrm{~kb} E c o \mathrm{RI}$ subfragment isolated from the original $9.3 \mathrm{~kb}$ genomic fragment $(D X S 52) .{ }^{10}$ It detects a $T a q \mathrm{I}$ and $M s p \mathrm{I}$ polymorphism. MN12 and DX13 are tightly linked to the locus defined by St $14-1^{11}$ and detect a $B g I I$ and $B g l I I$ polymorphism, respectively. hs7 is a cDNA of the red pigment gene which is $98 \%$ homologous to the green pigment gene. ${ }^{12} 13$ It detects a SacI polymorphism which can be difficult to interpret as both males and females can exhibit the same band pattern. For example, a subject who shows both an $18 \mathrm{~kb}$ and a $7.5 \mathrm{~kb}$ band could be either a heterozygous female B2 $(18 \mathrm{~kb}), \mathrm{B} 3(7 \cdot 5 \mathrm{~kb})$, a female homozygous for $B 1(18 \mathrm{~kb}+7 \cdot 5 \mathrm{~kb})$, or a male who types B1. However, if the subject's DNA is digested with the enzyme NotI and separated by pulsed field gel electrophoresis, the size of the fragment(s) detected by hs7 is a function of the number of red and green genes possessed by that person. ${ }^{14}$ In a molecular genetic study of 134 unrelated men, $18 \cdot 7 \%$ had one red and one green gene, $43 \cdot 3 \%$ had one red and two green genes, $15 \cdot 7 \%$ had one red and three green genes, $4.5 \%$ had one red and four green genes, and $2 \cdot 2 \%$ had one red and five green genes. ${ }^{15}$ This variability in the number of green genes makes this NotI-hs7 RFLP a highly informative polymorphism.

\section{DNA ANALYSIS}

DNA was extracted from whole blood using Biosystems 340A Nucleic Acid Extractor. DNA samples from each family were digested using the appropriate restriction enzyme for each probe. The fragments were separated on a $1 \%$ agarose gel. The DNA was transferred onto a nylon membrane (Amersham). The nylon membrane was prehybridised $(6 \times \mathrm{SSC}, 5 \times$ Denhardt's solution, $0 \cdot 1 \%$ SDS, $100 \mu \mathrm{g} / \mathrm{ml}$ denatured salmon sperm DNA) at $65^{\circ} \mathrm{C}$. The DNA probe was labelled with ${ }^{32} \mathrm{P}$ by random primer synthesis. ${ }^{16}$ The filter was hybridised $(6 \times$ SSC, $5 \times$ Denhardt's solution, $10 \%$ PEG, $0 \cdot 1 \%$ SDS, $100 \mu \mathrm{g} / \mathrm{ml}$ denatured salmon sperm DNA) overnight with the denatured ${ }^{32} \mathrm{P}$ labelled DNA probe at $65^{\circ} \mathrm{C}$. The filter was washed under the appropriate conditions and autoradiographed at $-70^{\circ} \mathrm{C}$ with Fuji XR film.

To detect the hs7-NotI polymorphism, cells from a lymphoblastoid cell line were harvested or white cells from $10 \mathrm{ml}$ whole blood were isolated and counted. Then $3 \times 10^{6}$ cells were mixed in $100 \mu \mathrm{l} 0.5 \%$ Incert agarose (ICN), aliquoted into a block former, and allowed to set at $4^{\circ} \mathrm{C}$. The agarose block was placed in NDS $(0.5 \mathrm{~mol} / 1$ EDTA, $1 \%$ sarcosyl, $10 \mathrm{mmol} / \mathrm{l}$ Tris, pH 9.5) containing $1 \mathrm{mg} / \mathrm{ml}$ Pronase E (Sigma) and left at $50^{\circ} \mathrm{C}$ for 24 hours. The NDS was washed from the agarose block in TE $(10 \mathrm{mmol} / \mathrm{l}$ Tris- $\mathrm{HCl} \mathrm{pH} 8.0$, $1 \mathrm{mmol} / \mathrm{l}$ EDTA), and the DNA digested overnight at $37^{\circ} \mathrm{C}$ using 30 units $N o t I$ enzyme (NBL). Half the agarose block was loaded onto a $1 \%$ agarose gel and the NotI digested DNA was separated by transverse alternating field electrophoresis (Beckman) for 18 hours at a 15 second switching interval. The DNA was depurinated $(0.25 \mathrm{~mol} / \mathrm{l} \mathrm{HCl})$ for 30 minutes and transferred onto a nylon membrane (Amersham). Hybridisation was performed under standard conditions.

\section{Results}

FAMILY A

All members from generations II and III had their plasma VLCFA measured. II 1 ( an obligate carrier) and her daughter III 3 (fig 1) had slightly raised C26:0 levels of 0.438 and $0.385 \mu \mathrm{g} / \mathrm{ml}$ but were within the 1 SD range. With this equivocal result in III 3 and the need for III 1 and III 3 to be certain of their carrier status, DNA analysis was performed on the family using St14-1 (DXS52). The TaqI digest showed the affected boy (III-4) to be without a variable TaqI fragment (fig 2A). II $\cdot 1$ and III $\cdot 3$ had only one variable TaqI fragment. The MspI polymorphism detected by St14-1 showed that no fragments were missing (fig 2B). Use of a $0.75 \mathrm{~kb}$ PvulI subfragment of the $3 \mathrm{~kb}$ St 14-1 probe on the TaqI digest showed the variable TaqI fragment had been comigrating with the $5.5 \mathrm{~kb}$ constant band (fig 2C). This variable TaqI fragment may represent a variant of the St 14-1 allele 2/2A. hs7 was used on NotI digested DNA separated by PFGE (fig 3).

From the DNA analysis it can be seen that II 1 (the obligate carrier with equivocal VLCFA levels), III $\cdot 3$ (her daughter with equivocal VLCFA levels), and III 4 (the affected boy) all have the same St14-1/hs7 haplotype. Based on the combination of VLCFA and DNA tests, III 3 was diagnosed as a carrier and was counselled accordingly: she therefore would be offered prenatal diagnosis.

By deduction, the $5.5 \mathrm{~kb}$ TaqI St14-1 fragment seen in II $\cdot 1$, III $\cdot 3$, and III $\cdot 4$ appears to have come from $I \cdot 2$. His brothers $I \cdot 3, I \cdot 4$, and $I \cdot 5$ all have the $4 \cdot 5$ $\mathrm{kb}$ fragment. There are several possibilities for the origin of the mutation in this family.

(1) I.2 may have been mildly affected with AMN which did not affect the quality of his life. As ALD and $A M N$ are suggested to have arisen from the same 
Family A

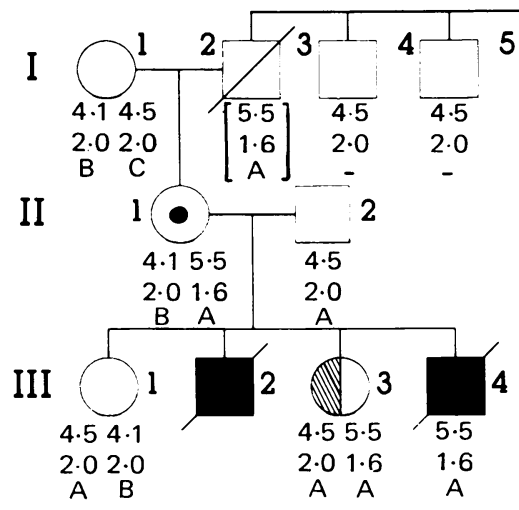

Family C

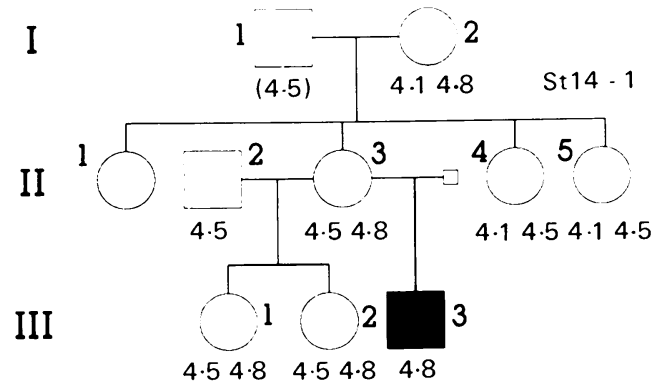

Family B

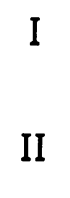

Family $\mathbf{B}$
$2 \cdot 0$ MAspl-St14 II

- Notl-hs7
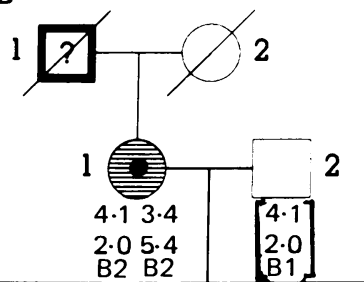

St 14 - 1 D $\times 13$ hs7
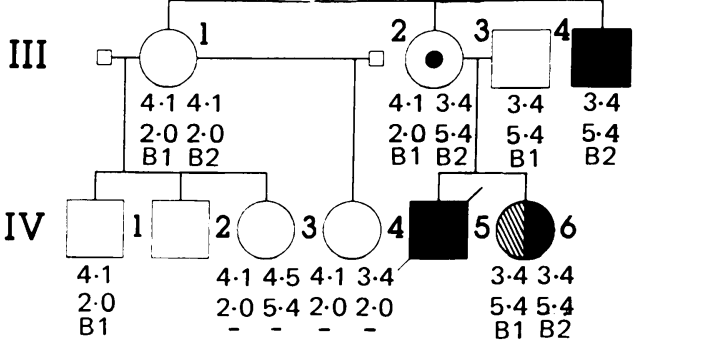

Family D
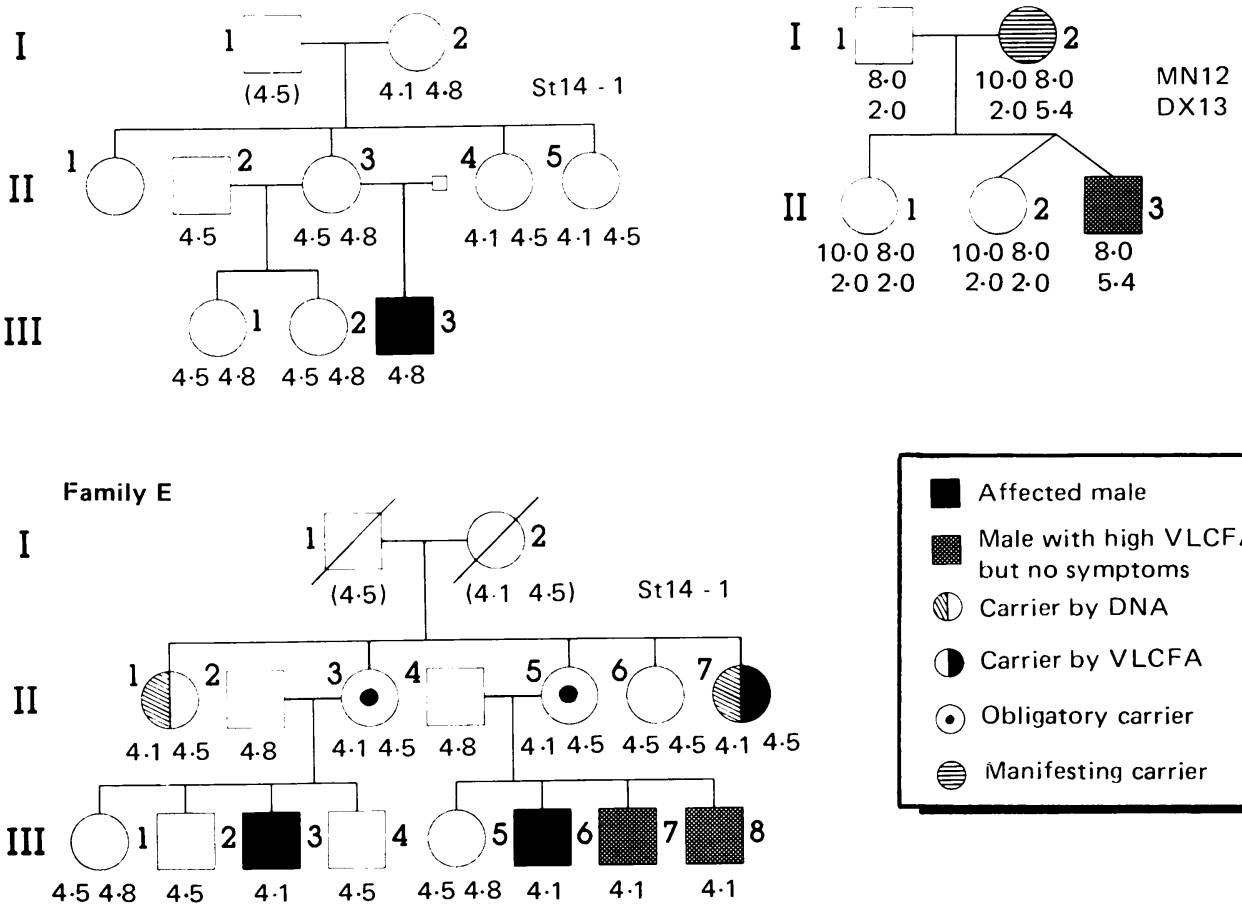

Affected male

Male with high VLCFA levels but no symptoms

(1) Carrier by DNA

- Carrier by VLCFA

- Obligatory carrier

Manifesting carrier

Figure 1 Pedigrees of the five families.

mutation, ${ }^{18}{ }^{19}$ it is possible that the disease gene was passed on to II $\cdot 1$ and then III $\cdot 2$ and III 4 where it manifested itself as ALD.

(2) The mutation may have occurred in $\mathrm{I} \cdot 2$ at gametogenesis and passed on to II 1 .
(3) II 1 is a gonadal mosaic.

(4) The mutation came from I 1 at meiosis. This is unlikely as the ALD gene would have had to crossover with the St14-1/hs7 haplotype in $\mathrm{I} \cdot 1$ and again in II $\cdot 1$. 

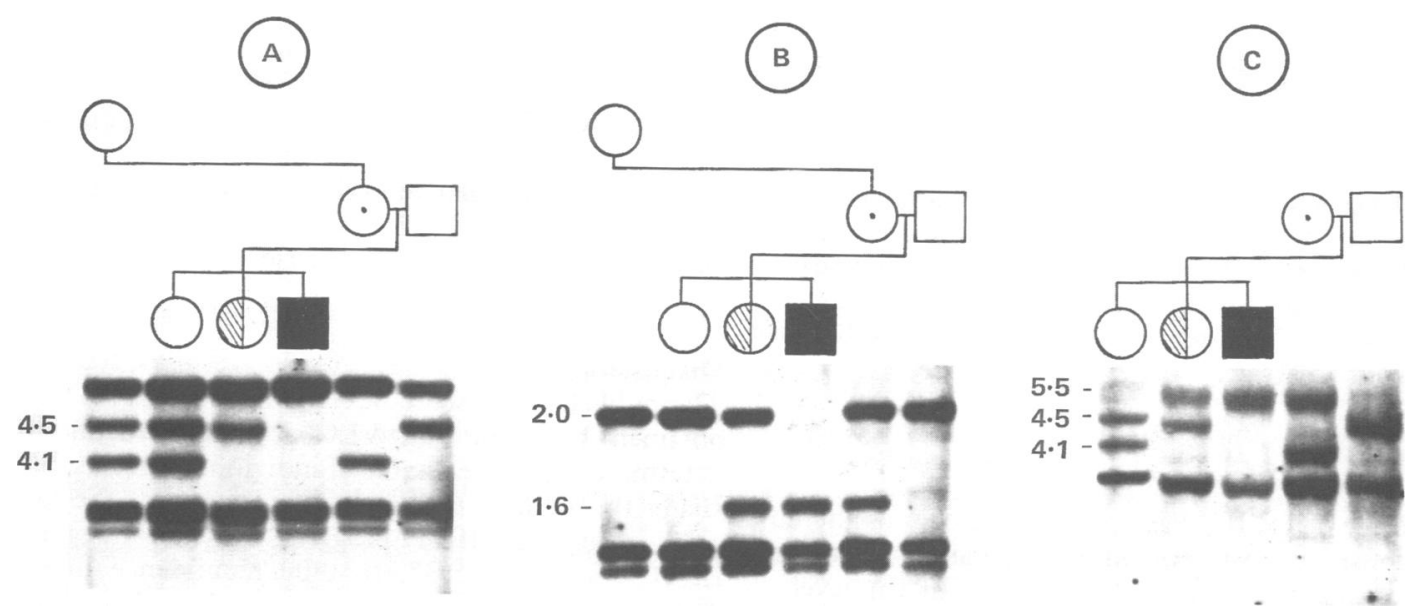

Figure 2 DNA analysis of family A. Hybridisation of St14-1 to a TaqI digest ( $A$ ) and an MspI digest (B), and of a subfragment of St 14-1 to the TaqI digest $(C)$.

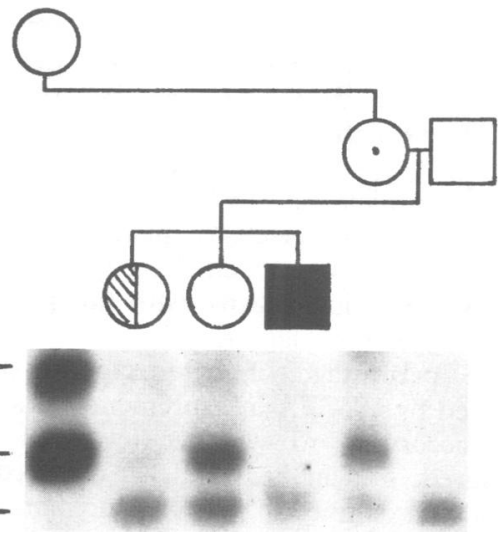

Figure 3 PFGE of a NotI digest of family $A$ hybridised with $h s 7$. The $145 \mathrm{~kb}$ fragment represents one red and one green pigment gene, the $180 \mathrm{~kb}$ fragment represents one red and two green pigment genes, and the $245 \mathrm{~kb}$ fragment represents one red and four green pigment genes.

\section{FAMILY B}

At the age of 36 years, $I \cdot 1$ developed weakness in his legs and was in a wheelchair by the time he was 40 years old. Three years later he died with a reported diagnosis of spinal myelitis, which may have been AMN. His daughter II $\cdot 1$ has spastic paraparesis, III $\cdot 4$ has AMN, and IV.5 had ALD. Members of this family (fig 1) who had their plasma VLCFA levels determined were either in the normal (1 SD range) or high range (2 SD above the normal mean), except III $\cdot 2$, whose $C 26: 0$ level lay between $1 S D$ and 2 SD above the normal mean and whose $\mathrm{C} 24 / \mathrm{C} 22$ levels were within the normal range. She had a son IV.5 affected with ALD. DNA analysis with St14-1, DX13, and hs7 showed the $3.4 \mathrm{~kb} \mathrm{St} 14-1 / 5.4 \mathrm{~kb}$ DX13/B2 hs7 haplotype is segregating with the high VLCFA levels and the disease. IV 6 is uninformative with St14-1 and DX13, but informative with hs7. Thus, prenatal diagnosis can be offered using the $S a c I$ polymorphism. This is based on the fact that an affected male fetus will have the B2 allele, and an unaffected male fetus will have the B1 allele. No DNA analysis was possible on IV 5 .

II 1 may be an exampe of selection by Lyonisation favouring the mutant allele in heterozygotes, ${ }^{5}$ where spastic paraparesis manifests itself later on in life. Also, in generation III AMN is manifesting, but in generation IV it is ALD. Though DNA analysis was not performed on IV $\cdot 5$, it is most likely that IV. 5 had the same St14-1/DX13/hs7 haplotype as III.4. This family supports the suggestion that the same gene defect is responsible for both ALD and AMN, ${ }^{18} 19$ but what factor(s) determine which disease a person has is uncertain.

\section{FAMILY C}

III 3 was diagnosed as having ALD. No other branch of the family was manifesting the disease, but III 1 and III 2 were concerned as to their carrier status (fig 1). Plasma VLCFA levels were measured in generations II and III. II $\cdot 3$, III 1 , and III 2 all had VLCFA levels between 1 and 2 SD above the mean. II $1, \mathrm{II} \cdot 4$, and II. 5 were all below the normal mean. DNA analysis with St14-1 showed that the affected boy, III $\cdot 3$, had the $4 \cdot 8 \mathrm{~kb}$ fragment, as did III $\cdot 1$, III $\cdot 2$, and II $\cdot 3$. I 2 has the $4 \cdot 8 \mathrm{~kb}$ and $4 \cdot 1 \mathrm{~kb}$ fragments. II $\cdot 1$, II $\cdot 4$, and II $\cdot 5$, who have normal VLCFA levels, have 
inherited the $4 \cdot 1 \mathrm{~kb}$ fragment. Based on these data and from experience with other families in this study, III $\cdot 1$ and III $\cdot 2$ were counselled as probably being carriers, with II $\cdot 1, \mathrm{II} \cdot 4$, and II $\cdot 5$ being counselled as non-carriers.

I 2 has come from a large sibship with nine brothers and three sisters. She has the $4 \cdot 8 \mathrm{~kb}$ fragment as does the affected boy III $\cdot 3$, but did not have her plasma VLCFA levels measured. Based on the fact that $I \cdot 2$ has come from a large normal sibship, it is likely that she is not a carrier.

\section{FAMILY D}

At the age of $11, \mathrm{II} \cdot 3 \mathrm{had}$ sporadic episodes of altered consciousness. Subsequent investigations showed impaired adrenal function and high VLCFA levels, and a cranial CT scan showed symmetrical areas of low attenuation in the white matter of the parietal and occipital lobes, typical of a leucodystrophy. II 3 is on replacement steroids, but at the age of 18 is not showing any symptoms of ALD. In the meantime, $\mathbf{I} \cdot 2$ had presented to a neurologist with signs of a spastic paraparesis. Plasma VLCFA measurements in the family (fig 1) show I.2 to have high levels of C26:0 and II $\cdot 1$ and II 2 to have levels of 0.385 and $0.347 \mu \mathrm{g} / \mathrm{ml}$, which are near the top of the 1 SD range. DNA analysis with St14-1 was uninformative, but MN12 and DX13, which are on either side of St14-1, were informative. II 3 has an MN12/DX13 haplotype which his sisters II $\cdot 1$ and II $\cdot 2$ have not inherited from $\mathbf{I} \cdot 2$. From these data, it appears that II $\cdot 1$ and II $\cdot 2$ are not carriers and were counselled accordingly.

In II $\cdot 3$ the onset of ALD may be delayed, or he may develop AMN later on in his life. Because of the nature of this kind of neurological disease, it is very difficult to give any prognosis to the parents.

\section{FAMILY E}

In this family (fig 1) III 3 and his cousin III. 6 had ALD. The two younger brothers of III 6 have high VLCFA levels and are presumed to be in the presymptomatic stage of ALD. All members in generations II and III had their plasma and fibroblast VLCFA levels tested. Difficulties arose in determining carrier status of the females, as subjects II 3 , II $\cdot 5$, and II 6 have VLCFA levels within the $1 \mathrm{SD}$ range in spite of $\mathrm{II} \cdot 3$ and $\mathrm{II} \cdot 5$ being obligatory carriers. The $\mathrm{C} 26 / \mathrm{C} 22$ ratio was slightly raised in II $\cdot 1$, but overall it was within the normal limits. II $\cdot 7$ has high levels of VLCFA, above 2 SD from the mean. Because of the equivocal results seen in II 3 and II $\cdot 5$, DNA analysis with St14-1 was performed. The ALD gene is segregating with the $4 \cdot 1 \mathrm{~kb} T a q I$ fragment. II $\cdot 1, \mathrm{II} \cdot 3, \mathrm{II} \cdot 5$, and II $\cdot 7$ all carry the $4 \cdot 1 \mathrm{~kb}$ TaqI fragment. II. 6 was found to carry the $4.5 \mathrm{~kb}$ TaqI fragment and had normal VLCFA levels. From these data, II $\cdot 1$ and II $\cdot 7$ were counselled as carriers. II 6 was counselled as not being a carrier, as were III $\cdot 1$ and III 5 who had normal VLCFA levels and did not carry the $4 \cdot 1 \mathrm{~kb}$ TaqI fragment.

hs7 was uninformative in this family. VLCFA tests were not possible on $I \cdot 1$ and $I \cdot 2$, but the DNA analysis suggests $\mathrm{I} \cdot 2$ was a carrier.

\section{Discussion}

The published lod score of ALD against St14-1 was obtained by using the VLCFA measurements to determine the carrier status of individual subjects. ${ }^{8} 18$ Using the same approach in these families, the lod score (using the LIPED program) for St14-1 against ALD was $Z \max =5.37, \theta=0.00$ (confidence limits 0.00 to 0.09 ). These results increase the lod score to $\mathrm{Zmax}=24 \cdot 47, \theta=0 \cdot 00$.

As no crossovers were observed between the probes used and ALD, the order of the probes with respect to the disease gene is still unknown. As MN12, St14-1, and DX13 are closely linked to one another, ${ }^{11}$ then in the rare case where St14-1 is uninformative (family D), DX13 and MN12 can be used. The SacI polymorphism detected by hs7 was not very informative in our families. The only time the SacI polymorphism was used with certainty was in family B where the allele B2 $(18 \mathrm{~kb})$, which was segregating with ALD, could be clearly distinguished. Therefore this family could be typed clearly with hs 7 , and IV $\cdot 6$, who was only informative with this probe, could be offered prenatal diagnosis.

The percentage of heterozygotes that can be detected by VLCFA measurements varies from 80 to 93\% according to whether levels in plasma are measured, or whether levels in cultured fibroblasts are also examined. ${ }^{61719}$ In our families, plasma specimens were sent to Dr Moser in Baltimore and normal results were not followed with skin biopsies. Unfortunately, only one of the four obligatory nonmanifesting heterozygotes had a C26:0 level above 1 SD from the control mean. This meant that the 17 at risk females in these families with normal VLCFA levels could not be reassured; two further at risk females had clearly high levels (IV.6 in family B and II.7 in family E). As DNA studies showed no crossovers between the DNA probes St 14-1, MN12, DX13, hs7 and unequivocal disease status in these families, we could use their inheritance patterns to determine the carrier status of all but six of the 17 possible carriers. The six who could not be firmly categorised were the mothers, aunts, and sisters of the isolated case in family $\mathrm{C}$, although risks could be assigned to them with a high degree of probability.

Of the 25 mothers, aunts, and sisters of index patients, two were manifesting carriers, five were obligatory heterozygotes (which included one of the 
manifesting carriers), two had high levels of plasma VLCFA but no neurological manifestations, two were carriers because of their St14-1 genotype but had normal VLCFA levels, 12 were considered not to be carriers because of their genotype and normal VLCFA levels, and three were assigned risks based on pedigree analysis and the finding of normal VLCFA levels (all from family C). Therefore, in the families with multiple cases, DNA analysis could define carrier status in all the at risk females who had VLCFA levels in the normal range and was useful in the one family with an isolated case. All the carrier females could be offered prenatal diagnosis using the DNA probes.

Further experience of the combined use of VLCFA measurements and DNA analysis will lead to more precise risks being calculated for those relatives of isolated cases who have levels in the high normal range. For example, in this study, two of four possible carriers with $\mathrm{C} 26: 0$ levels between the mean and $1 \mathrm{SD}$ were identified as a carrier through DNA analysis, and no woman with a C26:0 below the control mean was considered to be a carrier as a result of DNA analysis.

In this molecular genetic study, spastic paraparesis, ALD, and AMN were segregating together. The major defect in this kind of neurological disease may be the result of a mutation in a gene at $\mathrm{Xq} 28$, but the complexity of the disease suggests that other genes or secondary effects or both could account for the variety of manifestations.

We are grateful to the families for their cooperation in this study and to the following consultants for referring their patients: Drs D Riddoch (families A, $B$, and D), J Insley (families $C$ and $E$ ), and S Green (family E). We also thank $\mathrm{Dr} H$ W Moser for performing and interpreting the biochemical assays and $A$ Green for interpreting the biochemical assays in family E, Dr P Farndon for helpful discussions, comments, and critical reading of the manuscript, G S Higgins for DNA extraction, P M Rindl for technical assistance (family E), Dr J-L Mandel for the DNA probe St14-1, Dr K E Davies for the DNA probes MN12 and DX13, and Dr J Nathans for the DNA probe hs7. We gratefully acknowledge the financial support of The Endowment Fund Medical Research
Committee of the Former United Birmingham Hospitals and The Wellcome Trust.

1 Schaumburg HH, Powers JH, Raine CS, Suzuki K, Richardson EP. Adrenoleukodystrophy: a clinical and pathological study of 17 cases. Arch Neurol 1975;32:577-91.

2 Griffin JW, Goren E, Schaumburg H, Engel WK, Loriaux L. Adrenomyeloneuropathy: a probable variant of adrenoleukodystrophy. Neurology 1977;27:1107-13.

3 Singh I, Moser AE, Moser HW, Kishimoto Y. Adrenoleukodystrophy: impaired oxidation of very long chain fatty acids in white blood cells, cultured skin fibroblasts and amniocytes. Pediatr Res 1984;18:286-90.

4 Lazo O, Contreras M, Hashmi M, Stanley W, Irazu C, Singh I. Peroxisomal lignoceroyl-CoA ligase deficiency in childhood adrenoleukodystrophy and adrenomyeloneuropathy. Proc Natl Acad Sci USA 1988;85:7647-51.

5 Migeon BR, Moser HW, Moser AB, Axelman J, Sillence D, Norum RA. Adrenoleukodystrophy: evidence for $\mathrm{X}$ linkage, inactivation, and selection favouring the mutant allele in heterozygous cells. Proc Natl Acad Sci USA 1981;78:5066-70.

6 Moser HW, Moser AE, Trojak JE, Suplee SW. Identification of female carriers of adrenoleukodystrophy. F Pediatr 1983;103: 54-9.

7 Davies KE, Mandel JL, Weissenbach J, Fellows M. Report of the committee on the genetic constitution of the $\mathrm{X}$ and $\mathrm{Y}$ chromosomes. HGM9. Cytogenet Cell Genet 1987;46:277-315.

8 Aubourg PA, Sack GH Jr, Meyers DA, Lease JJ, Moser HW. Linkage of adrenoleukodystrophy to a polymorphic DNA probe. Ann Neurol 1987;21:349-52.

9 Aubourg PR, Sack GH Jr. Moser HW. Frequent alterations of visual pigment genes in adrenoleukodystrophy. Am $\mathcal{f} \mathrm{Hum}$ Genet 1988;42:408-13.

10 Oberlé I, Drayna D, Camerino G, White R, Mandel JL. The telomeric region of the human $\mathrm{X}$-chromosome long arm: presence of a highly polymorphic DNA marker and analysis of recombination frequency. Proc Natl Acad Sci USA 1985;82: 2824-8.

11 Patterson M, Kenwrick S, Thibodeau S, et al. Mapping of DNA markers close to the fragile site on the human X-chromosome at Xq27.3. Nucleic Acids Res 1987;15:2639-51.

12 Nathans J, Thomas D, Hogness DS. Molecular genetics of human colour vision: the genes encoding blue, green, and red pigments. Science 1986;232:193-202.

13 Nathans J, Piantanida TP, Eddy RL, Shows TB, Hogness DS. Molecular genetics of inherited variation in human colour vision. Science 1986;232:203-10.

14 Vollrath D, Nathans J, Davis RW. Tandem array of human pigment genes at Xq28. Science 1988;240:1669-72.

15 Drummond-Borg M, Deeb SS, Motulsky AG. Molecular patterns of X chromosome-linked color vision genes among 134 men of European ancestry. Proc Natl Acad Sci USA 1989;86:983-7.

16 Feinberg AP, Vogelstein B. A technique for radiolabelling DNA restriction endonuclease fragments to high specific activity. Anal Biochem 1984;137:226-7.

17 Moser HW, Moser AE, Singh I, O'Neill BP. Adrenoleukodystrophy: survey of 303 cases: biochemistry, diagnosis, and therapy. Ann Neurol 1984;16:628-41.

18 van Oost $\mathrm{BA}$, van Zandvoort $\mathrm{P}$, Hoogeboom A, et al. Tight linkage between adrenoleukodystrophy and DXS52. HGM9. Cytogenet Cell Genet 1987;46:708.

19 Bridge PJ, Graham GE, MacLeod PM, Lillicrap DP. An indirect method of carrier detection for adrenoleukodystrophy in female descendants of a gonadal mosaic. Am f Hum Genet 1989;45: 177A. 